\title{
Chemical Composition and Antibacterial Activity of Essential Oils Isolated From Leaves of Different Woody Trees Grown In Al-Jabel Al-Akhdar Region, Libya
}

\author{
Ahmed. S. O. Mohareb ${ }^{1}$, Ibrahim. E. A. Kherallah ${ }^{1}$, Mohamed. E. I. Badawy ${ }^{2}$, Mohamed. Z.M. Salem ${ }^{1}$ \\ and Hameda. A. Y. Faraj ${ }^{1,3}$
}

\begin{abstract}
The present study reports the variation in the essential oils (EOs) composition from needles and scale leaves of Pinus halepensis, Cupressus sempervirens and Juniperus phoenicea which collected from three different altitudes at Al-Jabel Al-Akhdar area, Libya. The impact of the altitude on the quantity and quality of EOs was studied. In addition, the antibacterial activity was evaluated using microdilution broth assay technique. The results showed that the highest percentages of the EOs yield were found in $P$. halepensis with $0.41,0.60$, and $0.43 \%$ for the altitudes of $125 \mathrm{~m}$ (I), 391m (II), and 851m (III), respectively, while the lowest percentages of the yield were found in J. phoenicea, with $0.15,0.07$, and $0.18 \%$ at altitudes of I, II, and III, respectively. Based on $P$. halepensis EOs analyses using GC/MS, 35 components have been detected, which represents $89.92,91.56$, and $86.44 \%$ for the altitudes of $I$, II and III, respectively. Furthermore, high percentages from the components of $\alpha$-pinene, $\beta$-pinene, $\alpha$-terpineol and caryophyllene were identified at the three tested altitudes. For $C$. sempervirens EOs, 33 components were identified representing $84.94,93.37$ and $99.48 \%$ for levels I, II and III, respectively. The highest percentages of the EOs components in this species were $\alpha$-pinene, terpinen-4ol and $\alpha$-terpiny acetate at the three tested elevations. However, the detected main components in $J$. phoenecea EOs were $\alpha$-pinene, $\alpha$-myrcene, $\alpha$-terpinyl acetate and $\gamma$ terpinene. The highest antibacterial activity was observed for the oils from $P$. halepensisat and $J$. phoenicea at altitude I against the Agrobacterium tumefaciens, Erwinia carotovora, Corynebacterium fascians and Pseudomonas solanacearum. While the EOs extracted from scale leaves of $C$. sempervirens obtained from trees growing at level II were the most active against the tested bacteria. The results of this work revealed the impacts of the environmental conditions on the EOs composition which affected significantly in its quantitative and qualitative performances. Consequently, their biological activities were varied considerably. Moreover, the obtained data offer the opportunity to choose EOs with preferential
\end{abstract}

${ }^{1}$ Department of Forestry and Wood Technology,

Faculty of Agriculture, Alexandria University, Egypt

${ }^{2}$ Department of Pesticide Chemistry and Technology,

Faculty of Agriculture, Alexandria University; Egypt

${ }^{3}$ Department of Forestry and Wood Technology,

Faculty of Agriculture, Alexandria University, Egypt and

Department of Forestry and Range Sciences,

Faculty of Natural Resources and Environmental Sciences

University of Omar Al Mukhtar, Libya.

*corresponding author: ahmed_mohareb@yahoo.com

Received July 11, 2016, Accepted August 8, 2016 compound for pharmaceutical, pesticides, perfume and food industries in such important region in Libya.

Keywords: Plant essential oils; Pinus halepensis; Cupressus sempervirens; Juniperus phoenicea; GC/MS analyses; antibacterial activity.

\section{INTRODUCTION}

In Al-Jabal Al-Akhdar region, the largest phytogeographical, is the richest vegetation and highest species diversity in Libya, The vegetation in this area is classified into three main groups; the first is coastal and low altitude vegetation dominated by shrubs and trees, which constitute about $60 \%$ of the plant life forms, the second is mid altitude vegetation with the highest species richness and dominated by shrubs and trees with over $60 \%$ of the plant life forms, and the third is characterized by mountain top vegetation dominated by herbs and few low shrubs constituting up to $90 \%$ of the plant life forms. In addition, the flora in this area comprises the richest vegetation and the highest number of species known in Libya (Hegazy et al. 2011). Although the AL-Jabal AL-Akhdar region represented $1 \%$ of the total area of the country, it is characterized by the large bio-diversity, as the number of plant species reach up of 1100 species from the total of plant species (2000 species) with about 75 species of plants that grow only in this region (Al-Sodany et al. 2003 and El-Barasi and Saaed 2013). Recently, an increase interest in natural substances extracted from plants has been observed in literatures due to their less hazardous effect on environment, as well as to find effective alternatives to the synthesized chemicals used as drugs and pesticides. In this context, plant secondary metabolites, such as essential oils, have been widely investigated because of their non-toxic nature and a wide spectrum of biological activities (Daferera et al. 2000; Mohamed et al. 2009; Mohareb et al. 2013; Abdelgaleil et al. 2014 and Djouahri et al 2014). Essential oils are liquid 
products, which can be extracted by steam or water distillation of plant parts (leaves, stems, bark, seeds, fruits, roots and plant exudates). They are an important crop in many parts of the world and their profitability is closely linked to both the profile and concentration of the oil in each plant. Furthermore, several studies showed great influence of the physical factors such as temperature, atmospheric pressure, wind velocity, increasing precipitation and altitude on the amount and composition of the EOs (Friend and Woodward 1990 and Korner 2007). On the other hand, several authors have been demonstrated the antimicrobial activity of the EOs (Trabelsi,. et al. 2014; Zeraib et al. 2014 and Ghabraie et al. 2016).

Therefore, the objective of the current research was to study the chemical composition using GC/MC and antibacterial activity of the essential oils from leaves of Pinus halepensis, Cupressus sempervirens and Juniperus phoenicea collected from three different altitudes in Al-Jabel Al-Akhdar area, Libya. The percentages of EOs of leaves from the selected trees, the influence of the altitude on the quantity and quality of EOs, identification of the most effective compounds were studied in details.

\section{MATERIALS AND METHODS}

\section{Plant materials}

Needles and scale leaves of three tree species namely, Pinus halepensis Mill, Cupressus sempervirens L. and Juniperus phoenicea L. were collected from three locations in AL-Jabal AL-Akhder, Libya. The trees were chosen and represented by three classes of different levels of altitude. The plant samples were collected from three places in AL-Jabal AL-Akhder region Sidi Alhemre (851m high), Wadi Alkuf (391m high), and Alwsita near the Sea level. The leaves were taken from the first branch of each tree during August, 2014.

\section{Isolation of essential oils}

The air-dried leaves $(100 \mathrm{~g})$ of the three species were cut into small pieces and subjected to hydrodistillation for $3 \mathrm{~h}$ with $500 \mathrm{ml}$ of distilled water using a Clevengertype apparatus. The essential oil was collected and stored in a refrigerator at $4{ }^{\circ} \mathrm{C}$ prior to analysis. The oil yield was calculated based on dry weight (v/w, \%) (Lograda et al. 2013).

\section{Analysis of essential oils}

The composition of the EOs was analyzed by gas chromatography mass spectrometry (GC/MS) with the following specifications: A Trace GC Ultra/Mass Spectrophotometer ISQ (Thermo Scientific) instrument equipped with a FID and a DB-5 narrow bore column. Helium was used as the carrier gas (flow rate of $1 \mathrm{ml}$ $\left.\min ^{-1}\right)$, and the oven temperature program was: $45-165^{\circ}$ $\mathrm{C}\left(4{ }^{\circ} \mathrm{C} \mathrm{min}{ }^{-1}\right)$ and $165-280{ }^{\circ} \mathrm{C}\left(15^{\circ} \mathrm{C} \mathrm{min}^{-1}\right)$ with post run (off) at $280{ }^{\circ} \mathrm{C}$. Samples $(1 \mu \mathrm{l})$ were injected at 250 ${ }^{\circ} \mathrm{C}$, with split/split-less injector (50:1 split ratio) in the split less mode flow with $10 \mathrm{ml} \mathrm{min}^{-1}$. The GC/MS was equipped with a ZB-5MS Zebron capillary column (length $30 \mathrm{~m} \times 0.25 \mathrm{~mm}$ ID, $0.25-\mu \mathrm{m}$ film thickness; Agilent).

All mass spectra were recorded in the electron impact ionization (EL) at 70 electron volts. The mass spectrometer was scanned from $\mathrm{m} / \mathrm{z}$ 50-500 at five scans per second. Peak area percent was used for obtaining quantitative data with the HP-Chem Station software (Agilent Technologies) without using correction factors. Identification of the essential oil constituents was performed on the basis of MS library of NIST and Wiley, (Davies 1990 and Adams 1995).

\section{In-vitro antibacterial assay}

\subsection{Tested bacteria}

Four plant pathogenic bacteria namely, Agrobacterium tumefaciens (Family: Rhizobiaceae), Erwinia carotovora (Family: Enterobacteriaceae), Corynebacterium fascians (Family: Nocardiaceae) and Pseudomonas solanacearum (Family: Pseudomonadaceae) were provided by Department of Pesticide Chemistry and Technology, Faculty of Agriculture, Alexandria University, Egypt. The bacterial strains were maintained on nutrient agar (NA: Peptone $5 \mathrm{~g}$, Beef extract $3 \mathrm{~g}, \mathrm{NaCl} 8 \mathrm{~g}$ ), medium at $37^{\circ} \mathrm{C}$.

\subsection{Broth microdilution technique}

The in vitro antibacterial activities as minimum inhibitory concentrations (MICs) of the EOs were determined by microdilution broth assay method using 2,3,5-triphenyltetrazolium chloride (TTC, Sigma) as a chromogenic marker. Nutrient broth (NB) medium was used to grow the bacterial strains to a final inoculum size of $5 \times 10^{5} \mathrm{CFU} / \mathrm{mL}$. The EOs were dissolved in dimethyl sulfoxide (DMSO) and diluted with distilled water to obtain a final stock solution of $1000 \mathrm{mg} / \mathrm{L}$. For the broth microdilution test, $20 \mu \mathrm{L}$ of each bacterial suspension in NB medium was added to the wells of a sterile 96- well microtitre plate already containing 40 $\mu \mathrm{L}$ of serially diluted compounds and $140 \mu \mathrm{L}$ NB medium. The final volume in each well was $200 \mu \mathrm{L}$. Control wells were prepared with culture medium, bacterial suspension, and solvent. The contents of each well were mixed on a micro plate shaker at $200 \mathrm{rpm} / \mathrm{L}$ min prior to incubation for $24 \mathrm{~h}$ at $37 \pm 2^{\circ} \mathrm{C}$. To indicate respiratory activity, the presence of color was determined after adding $10 \mu \mathrm{L} /$ well of TTC dissolved in water $(0.01 \%, \mathrm{w} / \mathrm{v})$ and incubated under appropriate cultivation condition for $30 \mathrm{~min}$ in dark. The absorbance was measured at $492 \mathrm{~nm}$ in an Ultra Micro 
plate Reader (Robonik, PVT.LTD). Positive controls were wells with a bacterial suspension. Negative controls were wells with growth medium and the tested compounds. All measurements of MIC values were repeated in triplicate. The MIC was the lowest concentration, where no viability was observed after 24 $\mathrm{h}$ on the basis of metabolic activity.

\section{Statistical analysis}

Statistical analysis was performed using the SPSS 21.0 software program (Statistical Package for Social Sciences, USA). The experimental design was a split plot with three replications in each elevation. The main plots were occupied by three species ( $P$. halepensis, $J$. phoenicea and $C$. sempervirenus). The sub-plots were allocated to three levels at altitude (I, II and III), respectively. In the antibacterial assessment, three plates were used at each concentration. The data were analyzed by one-way analysis of variance (ANOVA). Mean separations were performed by Student-NewmanKeuls (SNK) test and differences at $\mathrm{P}<0.05$ were considered as significant. The ANOVA and L.S.D procedures were done according to Steel and Torrie (1980).

\section{Yield of the essential oils}

RESULTS AND DISCUSSIONS

The results in Table (1) showed that the highest percentages of the yield were found in P. halepensis Mill., $0.41,0.60$, and $0.43 \%$ for the altitudes of $125 \mathrm{~m}$ (I), 391m (II), and $851 \mathrm{~m}$ (III), respectively, while the lowest percentages of the yield were found in $J$. phoenicea L., with $0.15,0.07$, and $0.18 \%$ at altitude of I, II, and III, respectively. Significant differences were found among the means of EO yields at the studied altitudes for $P$. halepensis MIill. and $C$. sempervirens L., while no significant differences among EO yields in $J$. phoenicea L. at the different altitudes. From the obtained data, it can be noted that the EO content varied significantly based on tree species and locations. The yield of EOs isolated from needles of $P$. halepensis Mill. obtained in our study is lower than that reported by Amri et al. (2013) and higher than that reported by Abi-Ayad et al. (2011) and Raho (2014) but it was relatively similar to that reported by Dob et al. (2005);
Fekih et al. (2014), and Hamrouni et al. (2015). Also, the yield of EOs from leaves of $C$. sempervirens L. obtained in this study was lower than that reported by Mazari et al. (2010); Elansary et al. (2012) and Amri et al. (2013), and lower than the yield of EOs from cone of Tunisian $C$. sempervirens L. which reported by Ben Nouri et al. (2015). The yield of EOs isolated from leaves of $J$. phoenicea L. obtained in this study was lower than that reported by Stasis et al. (1996); Mazari et al. (2010); Derwich et al. (2010) and Amalich et al. (2015), but it was relatively similar when compared to that reported by Angioni et al. (2003) and Achak et al. (2009).

\section{Chemical composition of essential oils}

\subsection{Chemical composition of essential oils of $\boldsymbol{P}$. halepensis}

Figure (1) showed that the EOs were mixture of numerous compounds. The data in Table (2) presented the constituents of EOs of $P$. halepensis with their retention times and peak area and some of them presented in trace amounts were discussed, in total 35 components were identified representing 89.92, 91.56, and $86.44 \%$ for needles of the trees growing at altitude I, II and III, respectively of the total EOs composition. The major components for level I were $\beta$-pinene $(19.93 \%), \alpha$-pinene $(13.56 \%)$, caryophyllene $(8.45 \%)$, germacrene D (8.40). While the major components for level II were caryophyllene $(24.85 \%), \alpha$-terpineol (11.44\%), $\beta$-pinene (7.90\%), $\beta$-pinene $(7.90 \%)$, also the major components for level III caryophyllene (27.23\%), phenethylisovalerate $(7.97 \%), \alpha$-caryophyllene $(6.34 \%)$.

Some compounds such as fenchol, borneol, pinocarveol, myrtenol and geraniol were found in the needles of the trees growing at altitude I and II, while compounds of copaene, phenyl ethyl tiglate, guaiol, muurolol, cembrene and thunbergol were found in those growing at altitude III only.

Generally, the samples showed variable composition, which are related to different sites and their characteristics. These data are in agreement with those obtained by Dob et al. (2005) Fekih et al. (2014) and Raho (2014) and were relatively similar with that reported by Govindarajan et al. (2016).

Table 1. Mean of essential oils yields $(\%)$ in the tree leaves at different levels of altitude in $P$. halepensis, C. sempervirens and J.phoenicea

\begin{tabular}{lccc}
\hline & \multicolumn{3}{c}{ Tree Species } \\
\cline { 2 - 4 } Altitude & $\boldsymbol{P .}$ halepensis & C. sempervirens & J. phoenicea \\
\hline Level I $(\% \pm$ SE) & $0.41^{\mathrm{b}} \pm 0.21$ & $0.29^{\mathrm{a}} \pm 0.04$ & $0.15^{\mathrm{a}} \pm 0.03$ \\
\hline Level II $(\% \pm$ SE) & $0.60^{\mathrm{a}} \pm 0.11$ & $0.15^{\mathrm{ab}} \pm 0.001$ & $0.07^{\mathrm{a}} \pm 0.01$ \\
\hline Level III $(\% \pm \mathrm{SE})$ & $0.43^{\mathrm{b}} \pm 0.24$ & $0.05^{\mathrm{b}} \pm 0.02$ & $0.18^{\mathrm{a}} \pm 0.04$ \\
\hline
\end{tabular}

(1) Means followed by the same letter(s) are not significant, but different letter are significant for each column.

(2) LSD for altitude $=0.149$ 
Table 2. Components of the essential oils from needles of $P$. halepensis at different altitudes in AL-Jabal AL-Akhdar region

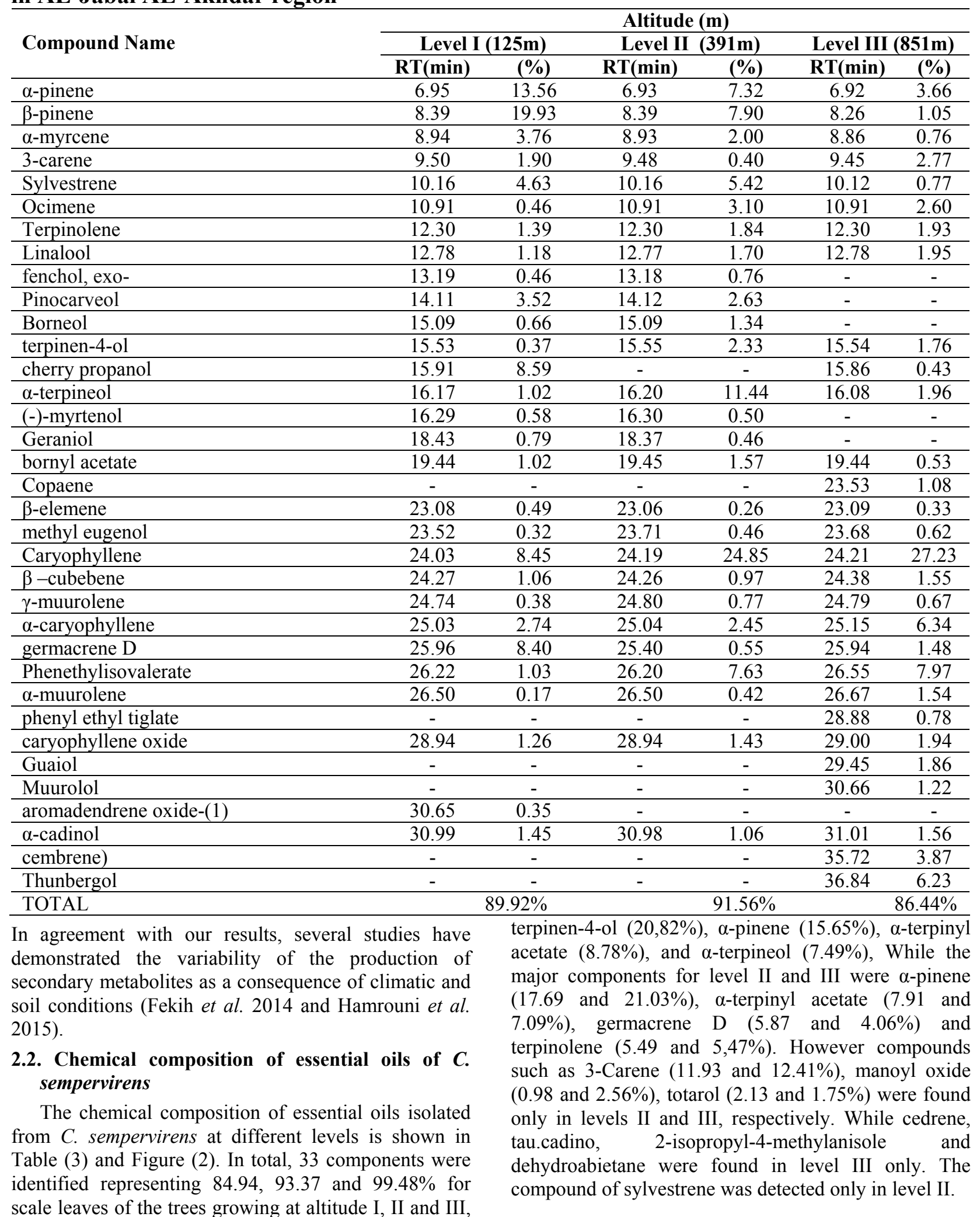


The chemical compositions revealed that these leaves have compositions relatively similar to those of other $C$. sempervirens EOs isolated from Tunisian plants Boukhris et al. (2012) and Ben-Nouri et al. (2015). The oils were predominantly composed of $\alpha$ pinene, (-) terpinen-4-ol and ( \pm -)- $\alpha$-terpinyl acetate as major constituent, while $\alpha$-myrcene, limonene, germacrene D and cedrol were found to be the second most important constituents of the $C$. sempervirensoil. Similar result was found by Mazari et al. (2010), who reported that $\alpha$-pinene was the major component of leaves EOs, but it is presented in upper content $(60.5 \%)$ compared with our study (15.05, 15.63 and 17.89\%). Also the percentage of $\alpha$-pinene was the same as obtained by Elansary et al. (2012), while, $\alpha$-pinene was reported as the second and the third major component, respectively, in the previous researches (Sacchetti et al. 2005 and Tapondjou et al. 2005).

\subsection{Chemical composition of essential oils of $J$. phoenecea}

The constituents of EOs of $J$. phoenecea with their retention times and percentages are shown in Table (4) and Figure (3). In total, 26 components were identified representing $85.92,91.08$ and $89.13 \%$ for branch lets of trees growing at altitude of I, II, and III, respectively, of the total EOs composition. The principal components of $J$. phoenecea EOs were $\alpha$-pinene $(26.25,20.44$ and $24.12 \%)$ and $\alpha$-terpinyl acetate $(12.06,12.34$ and $12.14 \%$ ) for scale leaves of trees growing at altitudes of I, II and III, respectively, also components $\gamma$ terpinene(16.86 and $19.39 \%$ ) and $\alpha$-thujene (6.67 and $7.8 \%$ ) for elevations II and III, respectively.

However, compounds of $\alpha$-cubebene and $\mathrm{T}$ muurolol were found in scale leaves of trees growing at altitudes of II and III. It is also noted that a carotol was detected in level I and III, respectively. The chemical analysis in this part revealed that these leaves have oil component relatively similar to those of other $J$. phoenicea EOs analyzed in Libya by Alfitori (2009) and also in Morocco by Derwich et al. (2010) and Amalich et al. (2015) who reported that the major component was $\alpha$-pinene and the other main constituents were $\alpha$-myrcene, $\gamma$-terpinene, linalool and germacrene D. In addition, Robert et al. (1996) studied the composition of $J$. phoenicea oil collected from the Portugal, Spain and Greece and they reported that the yields and the total oil obtained were $(0.41$ and $98.3 \%)$, (0.66 and 99\%) and (0.58 and 88\%), respectively, and the composition was characterized by a high content of $\alpha$-pinene $(34.1,53.5$ and $41.8 \%), \beta$-phellandrene (19.2, 5.9 and $3.5 \%$ ) and $\beta$ - caryophyllene $(0.22,1.0$ and $0.5 \%)$.
Such a discrepancy in chemical composition could be understood since several authors have documented significant species with specific variations in the concentrations of detected compounds and/or presence of others in high concentration. Moreover, the essential oil composition of $J$. phoenicea, as occurs with other medicinal and aromatic plants, is highly influenced by genetic and environmental factors (climatic, seasonal, geographical and geological).

\subsection{Antibacterial activity of essential oils isolated from needles of $P$. halepensis, branchlets of $C$ .sempervirens and $J$. phoenicea}

The antibacterial activity of EOs isolated from leaves or branch lets of $P$. halepensis, $C$. sempervirens and $J$. phoenicea against $A$. tumefaciens, E. carotovora, $C$. fascians and $P$. solanacearumare are presented in Table (5).

The EOs obtained from $P$. halepensis showed that the plant sample collected from the trees growing at altitude Icontained the most active product against the growth of A. tumefaciens, E. carotovora, C. fasciansand $P$. solanacearum among the three altitudes, with MIC values of $680,485,500$, and $390 \mathrm{mg} / \mathrm{L}$, respectively. However, the activity was decreased with the needles collected from the trees growing at altitude II (MIC 710, 465,875 and $580 \mathrm{mg} / \mathrm{L}$, respectively) and then level III which showed the lowest activity (MIC 755, 875, 945 and $585 \mathrm{mg} / \mathrm{L}$, respectively).

The EOs obtained from $C$. sempervirens showed that the scale leaves collected from the trees growing at altitude II contained the most active product against $A$. tumefaciens, E. carotovora, $C$. fascians and $P$. solanacearum with MIC values of 530, 585, 405, and $390 \mathrm{mg} / \mathrm{L}$, respectively. However, the activity was decreased with the altitudes I and III, respectively.

The EOs obtained from $J$. phoenicea showed that the scale leaves collected from the trees growing at altitude I the most active oils among the three altitudes against the growth of $A$. tumefaciens, E. carotovora, $C$. fascians and $P$. solanacearum with MIC 680, 580, 520 and $450 \mathrm{mg} / \mathrm{L}$, respectively. However, the scale leaves collected from the trees growing at altitude III showed the lowest activity with MIC of 940, 670, 735 and 650 $\mathrm{mg} / \mathrm{L}$, respectively.

According to Fekih, et al. (2014), the EO of $P$. halepensis showed good inhibitory effects on some tested microorganisms including Lysteria monocytagenes, Klebsiella pneumonia, Enterococcus faecalis and Acinetobacter baumanii with inhibition zones 10, 10, 9, $9.5 \mathrm{~mm}$, respectively. 


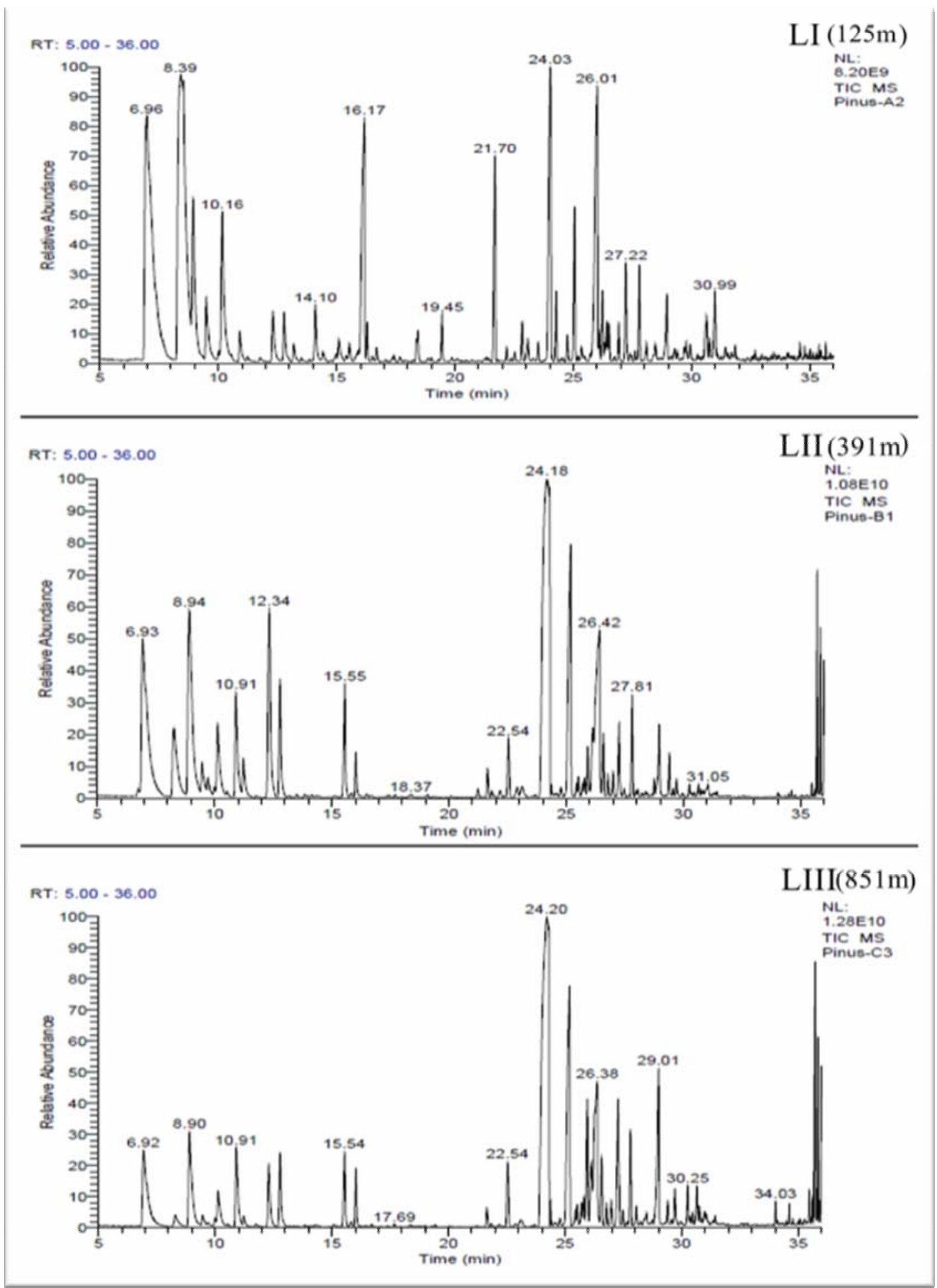

Figure 1. GC/MS chromatograms of essential oils of $P$. halepensis, needles at different altitudes in AL-Jabal AL-Akhdar region 


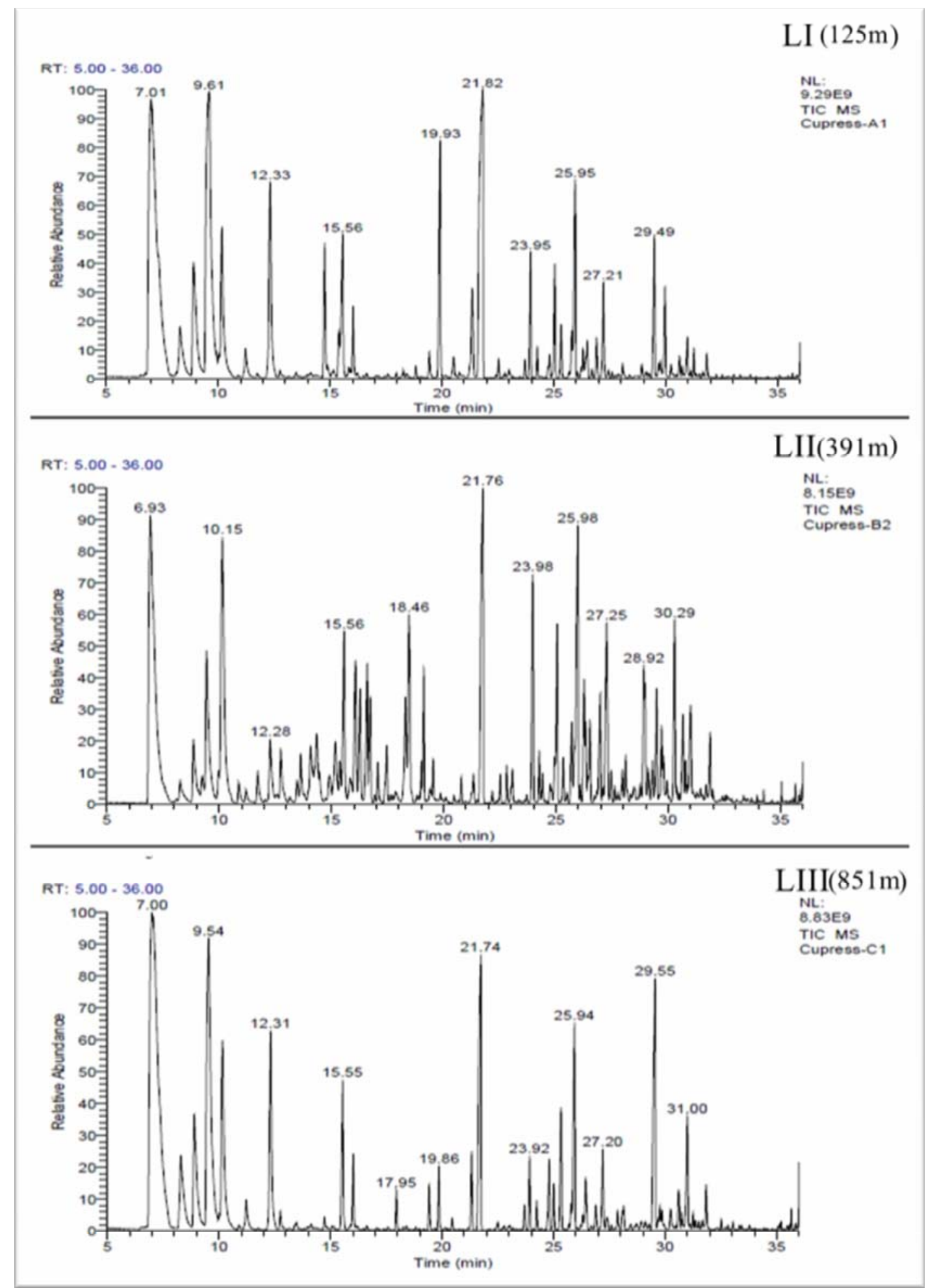

Figure 2. GC/MS chromatograms of essential oils of $C$. sempervirens leaves at different altitudes in AL-Jabal AL-Akhdar region 


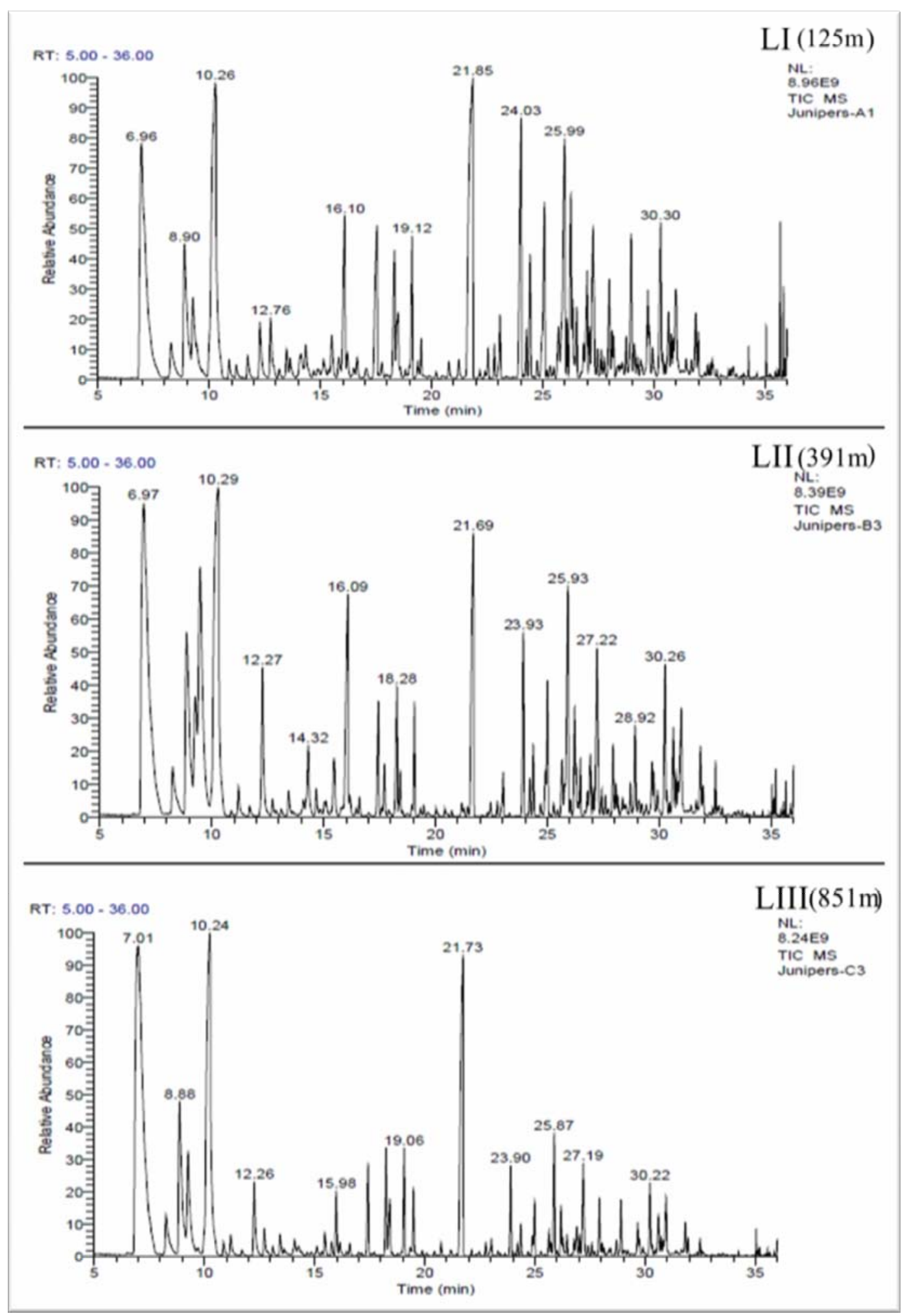

Figure 3. GC/MS chromatograms of essential oils of $\boldsymbol{J}$. phoenicea leaves at different altitudes in AL-Jabal AL-Akhdar region 
Table 4. Components of the essential oils from scale leaves of $J$. phoenecea at different altitudes in AL-Jabal AL-Akhdar region

\begin{tabular}{|c|c|c|c|c|c|c|c|}
\hline \multirow{3}{*}{\multicolumn{2}{|c|}{ Compound Name }} & \multicolumn{6}{|c|}{ Altitude (m) } \\
\hline & & \multicolumn{2}{|c|}{ Level I (125m) } & \multicolumn{2}{|c|}{ Level II (391m) } & \multicolumn{2}{|c|}{ Level III (851m) } \\
\hline & & RT(min) & $(\%)$ & RT(min) & $(\%)$ & RT(min) & $(\%)$ \\
\hline$\alpha$-pinene & & 6.98 & 26.25 & 6.93 & 20.44 & 6.94 & 24.12 \\
\hline$\alpha$-myrcene & & 8.87 & 3.81 & 8.88 & 6.67 & 8.89 & 7.88 \\
\hline$\alpha$-thujene & & 9.24 & 1.69 & 9.25 & 3.70 & 9.26 & 3.57 \\
\hline$\gamma$-terpinene & & 11.21 & 0.75 & 10.23 & 16.86 & 10.23 & 19.39 \\
\hline Terpinolene & & 12.28 & 1.23 & 12.25 & 1.74 & 12.26 & 2.09 \\
\hline$\alpha$-terpineol & & 16.00 & 0.97 & 15.98 & 1.91 & 15.99 & 1.98 \\
\hline Linalool & & 17.55 & 5.13 & 17.45 & 1.83 & 12.72 & 0.43 \\
\hline Piperitone & & 18.35 & 4.46 & 18.23 & 1.14 & 18.21 & 0.92 \\
\hline isopulegyl acetate & & 19.13 & 4.49 & 19.06 & 2.58 & 19.04 & 1.09 \\
\hline$\alpha$-terpinyl acetate & & 21.85 & 12.06 & 21.73 & 12.43 & 21.73 & 12.14 \\
\hline Caryophyllene & & 23.98 & 5.19 & 23.93 & 3.42 & 23.89 & 1.38 \\
\hline$\gamma$-elemene & & 24.38 & 0.86 & 24.36 & 0.55 & 24.36 & 0.96 \\
\hline$\alpha$-cubeben & & - & - & 24.90 & 0.61 & 24.89 & 0.35 \\
\hline germacreneD & & 25.94 & 5.02 & 25.92 & 4.62 & 25.68 & 2.08 \\
\hline cubebene) & & 26.26 & 2.81 & 26.21 & 0.74 & 26.19 & 1.04 \\
\hline$\alpha$-cadinene & & 27.26 & 1.08 & 27.22 & 3.08 & 27.18 & 2.18 \\
\hline Elemol & & 27.96 & 1.36 & 27.94 & 1.53 & 27.92 & 1.06 \\
\hline caryophyllene oxi & & 28.93 & 1.18 & 28.92 & 1.15 & 28.90 & 0.58 \\
\hline humulene epoxide & & 29.72 & 1.21 & 29.67 & 0.69 & 29.66 & 0.59 \\
\hline $\begin{array}{l}\text { tricyclo[5.2.2.0(1, } \\
\text { methylene-6,8,8-tr }\end{array}$ & $\begin{array}{l}\text { decan-3-ol, 2- } \\
\text { hyl- }\end{array}$ & 29.79 & 0.53 & - & - & - & - \\
\hline Cubenol & & 30.60 & 0.27 & 30.25 & 2.25 & 30.22 & 1.39 \\
\hline tau.-muurolol & & - & - & 30.62 & 1.23 & 30.60 & 0.86 \\
\hline Cedrol & & 30.95 & 0.63 & - & - & - & - \\
\hline$\alpha$-cadinol & & 30.96 & 1.42 & 30.98 & 1.91 & 30.95 & 1.40 \\
\hline Carotol & & 36.80 & 2.44 & - & - & 31.94 & 0.41 \\
\hline Totarol & & 38.62 & 1.08 & 38.63 & 0.88 & 38.63 & 1.24 \\
\hline TOTAL & & & $85.92 \%$ & & $91.08 \%$ & & $89.13 \%$ \\
\hline \multicolumn{8}{|c|}{$\begin{array}{l}\text { Table 5. Antibacterial activity of essential oils isolated from } P \text {. halepensis, } J \text {. phoenicea and } \\
C \text {. sempervirens trees against } A \text {. tumefaciens, } E \text {. carotovora, } C \text {. fascians and } P \text {. solanacearum }\end{array}$} \\
\hline \multirow[b]{2}{*}{ Tree species } & \multirow[b]{2}{*}{ Altitude } & \multicolumn{6}{|c|}{ MIC $(\mathrm{mg} / \mathrm{L})$} \\
\hline & & $\begin{array}{c}\text { A. } \\
\text { Tumefaciens }\end{array}$ & $\begin{array}{c}\text { E. } \\
\text { carotovora }\end{array}$ & & $\begin{array}{c}\text { C. } \\
\text { Fascians }\end{array}$ & solar & icearum \\
\hline \multirow[t]{3}{*}{ P. halepensis } & I & 680 & 485 & & 500 & & 390 \\
\hline & II & 710 & 465 & & 875 & & 880 \\
\hline & III & 755 & 875 & & 945 & & 85 \\
\hline \multirow[t]{3}{*}{ C. sempervirens } & I & 640 & 895 & & 810 & & +10 \\
\hline & II & 530 & 585 & & 405 & & 390 \\
\hline & III & 750 & 950 & & 760 & & 550 \\
\hline \multirow[t]{3}{*}{ J. phoenicea } & I & 680 & 580 & & 520 & & 550 \\
\hline & II & 955 & 800 & & 960 & & 310 \\
\hline & III & 940 & 670 & & 735 & & 50 \\
\hline
\end{tabular}


Moreover, the antibacterial activity of the EO of $J$. phoenicea could be associated with major constituents such as $\alpha$-pinene, $\delta$-3-carene, $\alpha$-terpineol, $\beta$-myrcene, limonene, $\gamma$-terpinene, and $\alpha$-amorphene. These components have been reported to display antibacterial effects (Ennajar, et al., 2009). In addition, the results of antibacterial activity of EOs isolated from $C$. sempervirens showed that the oils inhibited the growth of bacterial strains with lower MIC values from 390 to $585 \mathrm{mg} / \mathrm{L}$ for all bacteria depended on susceptibility of the tested bacteria. However, the MIC values were highest than those reported in the other studies, which showed wider inhibition zones at very low concentrations (Toroglu, 2007 and Ben Nouri, et al, 2015).

\section{CONCLUSION}

In this study, we noticed a significant difference in yields and chemical composition of leaves essential oils of $P$. halepensis, $C$. sempervirens and $J$. phoenicea, which existed naturally at different altitudes in Al-Jabel Al-Akhdar area, Libya. Although the main components of the all oils are common, their percentages are different based on the tree species and altitude. The results of antibacterial activities for the obtained essential oils showed distinct influences according to tree location for the same species. The MIC value of essential oils isolated from the tested tree species against the bacteria used in this study showed antibacterial potentials against Gram-positive as well as Gram-negative bacteria. The variation in the chemical composition of essential oils might be responsible for the different antibacterial activities. In conclusion, considerable qualitative and quantitative differences in yields, oil composition and antibacterial activities were detected in the studied tree species at different altitudes. These differences resulted from an adaptive process in the tested tree species to particular ecological conditions at the different altitudes.

\section{REFERENCES}

Abdelgaleil, S. A. M., M. M. G. Saad and B. Y. Hassan. 2014. Chemical composition and inhibitory effects of essential oils on germination and seedling growth of barnyard grass, Echinochloa crusgalli L. Alexandria Science Exchange Journal, 35: 278-287.

Abi-Ayad, M., F. Z. Abi-Ayad, H. A. Lazzouni and S. A. Rebiahi .2011. Antibacterial activity of Pinus halepensis essential oil from Algeria (Tlemcen) J. Nat. Prod. Plant Resour. 1 (1): 33-36.

Achak, N., A. Romane, M. Alifriqui, and R. P. Adams .2009. Chemical studies of leaf essential oils of three species of Juniperus from Tensift AlHaouz-Marrakech region (Morocco).Journal of Essential Oil research, 21:337-341.
Adams, R. P. 1995. Identification of essential oil Components by Gas Chromatography/Mass Spectrometry, Allured Publishing, CarolStream, Ill, USA.

Alfitori, M. O. M. 2009. Determination of biomass and study of wood properties of Juniperus phoenicea tree grown in AL-Jabel AL-Akhder.M.Sc. Forestry and Range Sciences Dept., Omar Al Mukhtar University.

Al-Sodany, Y. M., M. N. Shehata and K. H. Shaltout .2003. Vegetation along an elevation gradient in Al-Jabal AlAkhdar, Libya. International Journal of Mediterranean Ecology, 29 (2):125-138.

Amalich, S., N. Zekr, N. D. K .Soro, K. Fadili, Y. Khabba, M. Mahjoub, E. L. Akdim and T. ZAÏR .2015. Chemical characterization and antibacterial evaluation of Juniperus phoenicea L. leaves and fruits' essential oils from eastern high Atlas (Morocco).International Journal of Innovation and Applied Studies, 13(4): 881-889.

Amri, I., L. Hamrouni, M. Hananac, S. Gargourid, T. Fezzanib and B. Jamoussi, B. 2013. Chemical composition, physico-chemical properties, antifungal and herbicidal activities of Pinus halepensis Miller essential oils .Biological Agriculture and Horticulture, 29 (2): 91106.

Angioni, A., A. Barra, M. T. Russo, V. Coroneo, S. Dessias and P. Cabras . 2003. Chemical composition of the essential oils of Juniperus from ripe and unripe berries and leaves and their antimicrobial activity. J. Agric. Food Chem, .51: 3073-3078.

Bakkali, F., S. Averbeck, D. Averbeck and M. Idaomar . 2008. Biological effects of essential oils -A review. Food and Chemical Toxicology, 46 (2):446-475.

Bekhechi, C.; Atik-Bekkara F. and Abdelouahid, D. E. 2008. Composition et activite' antibacte'rienne des huiles essentielles d'Origanum glandulosumd'Alge'rie. Phytothe'rapie, 6: 153-159.

Ben Nouri, A., W. Dhifi, S. Bellili, H. Ghazghazi, C. Aouadhi, A. Chérif, M. Hammami and W. Mnif. W. 2015. Chemical composition, antioxidant potential and antibacterial activity of essential oil cones of Tunisian Cupressus sempervirens. Journal of Chemistry, Article ID 538929, 8 pages

Boukhris, M., G. Regane, T. Yangui, S. Sayadi and M. Bouaziz . 2012. Chemical composition and biological potential of essential oil from Tunisian Cupressus sempervirens L. Journal of Arid Land Studies, 22(1):329 332.

Daferera, D. J., B. N. Ziogas and M. G. Polissiou .2000. GCMS Analysis of essential oils from some Greek aromatic plants and their fungitoxicity on penicillium digitatum.J. Agric. Food Chem, 48: 2576-2581. 
Davies, N. W. 1990. Gas chromatographic retention indices of monoterpenes and sesquiterpenes on methyl silicone and Carbowax 20M phases. Journal of Chromatography A, 503, 1-24. British Pharmacopeia (1998)(Vol. II). HMSO, London.

Derwich, E., Z. Benzian and A. Boukir. 2010. Chemical composition of leaf essential oil of Juniperus phoenicea and evaluation of its antibacterial activity. Int. J. Agric. Biol, 12(2).199-204.

Djouahri, A., S. Boualema, I. Boudarenea and A. Baaliouamera .2014. Geographic's variation impact on chemical composition, antioxidant and anti-inflammatory activities of essential oils from wood and leaves of Tetraclinis articulata (Vahl) Masters. Ind. Crops Prod.

Dob, T., T. Berramdane and C. Chelgoum. 2005. Chemical composition of essential oil of Pinus halepensis Miller growing in Algeria, C. R. Chimie 8:1939-1945.

Elansary, O. H., M. Z. M. Salem, N. A. Ashmawy and M. M. Yacout .2012. Chemical composition, antibacterial and antioxidant activities of leaves essential oils from Syzygiumcumini L., Cupressus sempervirens L. and Lantana camara L. from Egypt. Journal of Agricultural Science, 4(10): 144-152.

El-Barasi, Y. M. M. and M.W. B. Saaed .2013. Threats to plant diversity in the North Eastern part of Libya (El-Jabal El-Akahdar and Marmarica Plateau). Journal of Environmental Science and Engineering, 2: 41-58.

Ennajar, M., J. Bouajila, A. Lebrihi, F. Mathieu, M. Abderraba, A. Raies and M. Romdhane . 2009. Chemical composition and antimicrobial and antioxidant activities of essential oils and various extracts of Juniperus phoenicea L. (Cupressacees). Journal of Food Science, (74) 7:364-371.

Fekih, N., H. Allali, S. Merghache, F. Chaïb, D. Merghache, M. El Amine. N. Djabou, A. Muselli, B. Tabti and J. Costa .2014. Chemical composition and antibacterial activity of Pinus halepensis Miller growing in West Northern of Algeria. Asian Pac J Trop Dis. 4(2): 97-103.

Friend, A. D. and F.I. Woodward .1990. Evolutionary and ecophysiological responses of mountain plants to the growing season environment, Adv. Ecol Res. 20: 59-124.

Ghabraie, M., Vu. K. Dang, L. Tata, S. Salmieri and M. Lacroix . 2016. Antimicrobial effect of essential oils in combinations against five bacteria and their effect on sensorial quality of ground meat. Food Science and Technology, 66:332-339.

Govindarajan, M., M. Rajeswary and G. Benelli . 2016. Chemical composition, toxicity and non-target effects of Pinus kesiya essential oil: An eco-friendly and novel larvicide against malaria, dengue and lymphatic filariasis mosquito vectors. Ecotoxicology and Environmental Safety, 129: 85-90.
Hamrouni, L., M. Hanana, I. Amri, A. Romane, S. Gargouri and B. Jamoussie .2015. Allelopathic effects of essential oils of Pinus halepensis Miller chemical composition and study of their antifungal and herbicidal activities. Archives of phytopathology and plant protection, 48(2): 145-158.

Hegazy, A., H. F. Kabiel and O. S. Sharashy .2011. Vegetation and species altitudinal distribution in Al-Jabal Al-Akhdar landscape, Libya. Pak. J. Bot, 43(4): 18851898.

Korner, C. 2007. The use of 'altitude' in ecological research TRENDS in Ecology and Evolution, 22(11): 568-573

Lograda, T., M. Ramdani, A. Kiram, P. Chalard and G. Figueredo. 2013. Variation of essential oils comp osition of Pituranthoss coparius in Algeria.Global. J Res. Med.Plants and Indigen, Med. 2: 1-9.

Mazari, K., N. Bendimerad, C. Bekhechi and X. Fernandez. 2010. Chemical composition and antimicrobial activity of essential oils isolated from Algerian Juniperus phoenicea L. and Cupressus sempervirens L. Journal of Medicinal Plants Research, 4(10): 959-964.

Mohamed, M. L. E., S. A. M. Abdelgaleil and M. A. Abdel Rasoul .2009. Potential of essential oils to control Sitophilus oryzae (L.) and Tribolium castaneum (Herbst) on stored wheat. Alexandria Science exchange Journal, 30: 419-429.

Mohareb, S. O. A., S. Abdelgaleil and M. Badawy .2013. Chemical composition and antifungal activity of essential oils isolated from Egyptian plants against wood decay fungi. J Wood Sci., 59:499-505.

Raho, G. B. 2014. Antibacterial potential of essential oils of the needles of Pinus halepensis against Staphylococcus aureus and Escherichia coli. Journal of Coastal Life Medicine, 2(8): 651-655.

Robert, P. A., A. F. Barrero and A. Lara .1996. Comparisons of the leaf essential oils of Juniperus phoenicea. J. Essent. Oil Res., 8: 367-371.

Sacchettia, G., S. Maiettia, M. Muzzolia, M. Scagliantib, S. Manfredinib, M. Radicecand R. Brunid .2005. Comparative evaluation of 11 essential oils of different origins as functional antioxidants, antiradicals and antimicrobials in foods. Food Chemistry, 91,4: 621-632.

Stasis, V., E. Verykokidou, A. Loukis, C. Harvala and S. Philianos .1996. The antimicrobial activity of the essential oils of four Juniperus species growing wild in Greece. .Flavour and fragrance journal, 11:71-74.

Steel, R. G. and Torrie. J. H. 1980. Principles and Procedures of Statistics 2nd ed. McGraw Hill, New York, U.S.A.

Tapondjoua, A. L., C. Adlerb, D. A. Fontemc, H. Boudaa and C. Reichmuth .2005. Bioactivities of cymol and essential oils of Cupressus sempervirens and Eucalyptus saligna against Sitophilus zeamais Motschulsky and Tribolium confusum du Val. Journal of Stored Products Research, 41: 91-102. 
Toroglu, S. 2007. In vitro antimicrobial activity and antagonistic effect of essential oils from plant species. Journal of Environmental Biology, 28(3) 551-559.

Trabelsi, D., A. Haj Ammar, F. Bouabdallah, and F. Zagrouba .2014. Antioxidant and antimicrobial activity of essential oils and methanolic extracts of Tunisian Citrus aurantium L. Journal of Environmental Science, Toxicology and Food Technology,5(II):18-27.
Zeraib, A., M. Ramdani, L. Boudjedjou, P. Chalard and G. Figuredo. 2014. Chemical composition and antibacterial activity of Juniperus thurifera L. essential oils J. BioSci. Biotech, 3(2): 147-154.

\section{الملذص العري}

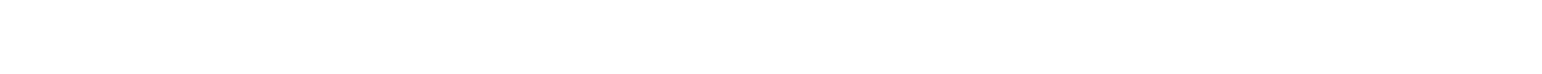

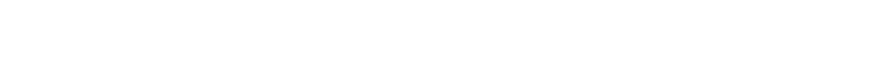

لحمد صدقي محارب، ابراهيم السيد خير اله، محمدطاهر بدوي، محمد زيدانسالم، حمية عبد النبي يووف

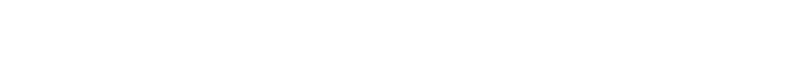

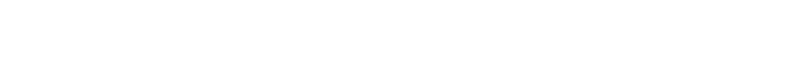
بن بنب $\beta$-Pinene, $\alpha$-caryophllene , - $\alpha$-terpineol, $\alpha$-pinene مختلفة في النوع الولحد والنلمي على إرقاعات مختلفة مما

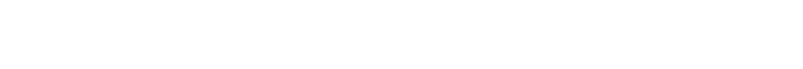

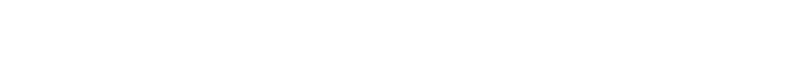
ارتبطا مبلثرا بالإرفاع عنسطح البحن البحر.

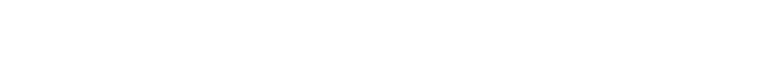

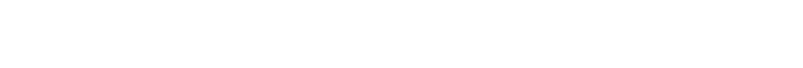

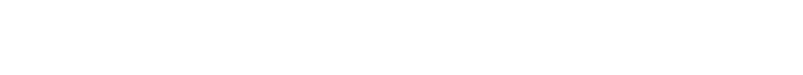
terpinen-4-o1, $\alpha$ - terpiny acetate, $\alpha$-pinene

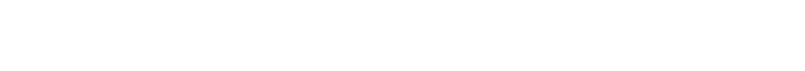

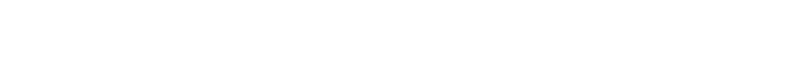

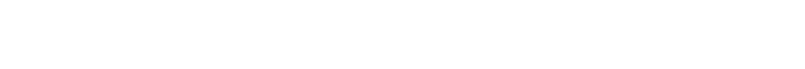
تركييب ونوعية الزيوت الطيارة في ذك النوع للشجري.

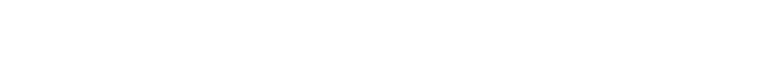

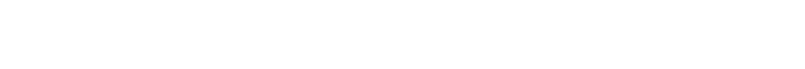

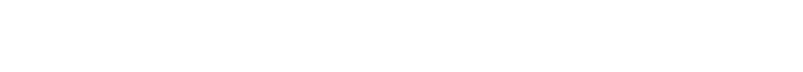

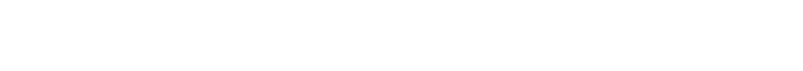
. $\alpha$-terpinyl acetate ، $\gamma$-terpinene ، $\alpha$-myrcene ، $\alpha$-pinene

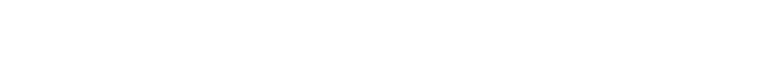

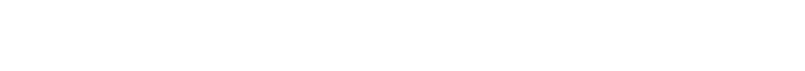

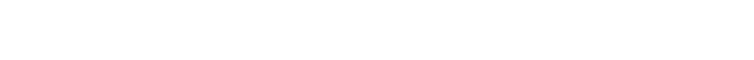

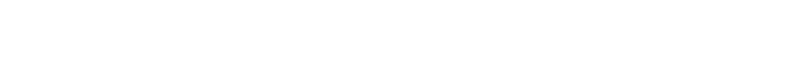

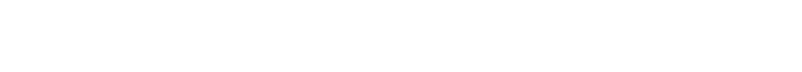

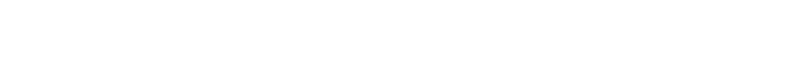

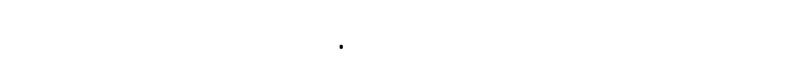

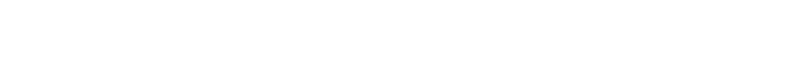

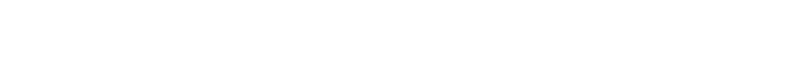

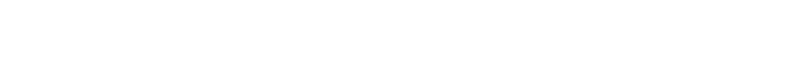

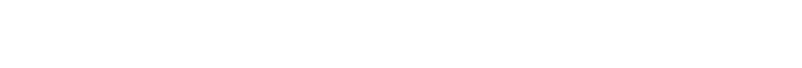
لمستخدلم المبيدات الصناعية المخلقة.

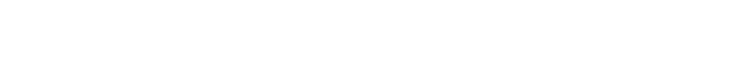

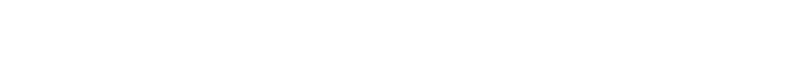

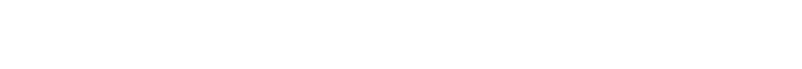

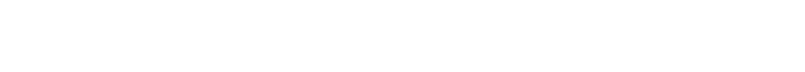

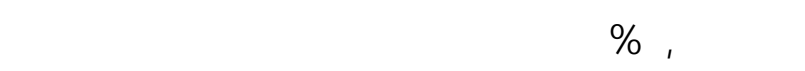

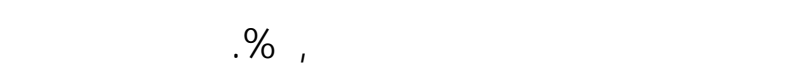

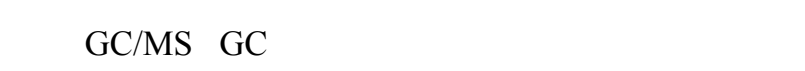

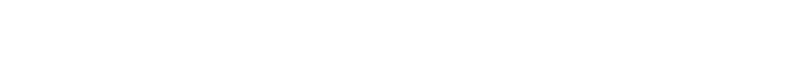

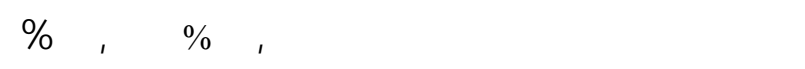

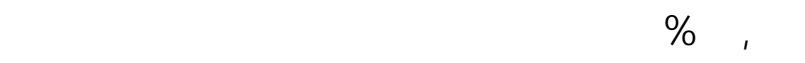

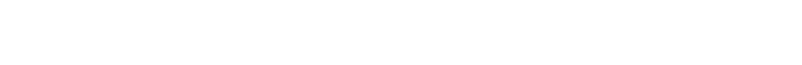
على الترقب. وعند إجراء عملية التعرف على (III ,II ,I) 


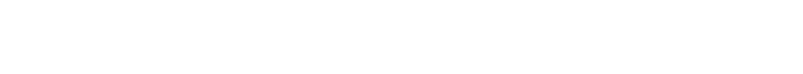

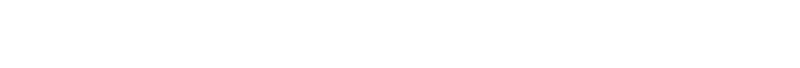

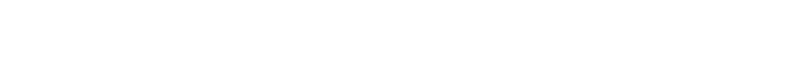

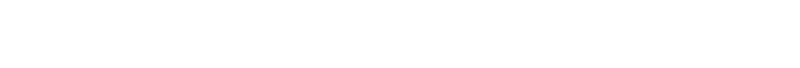

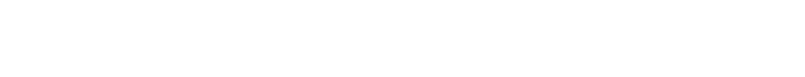

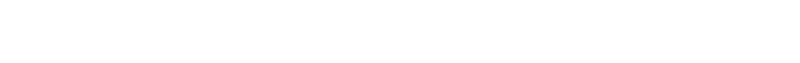

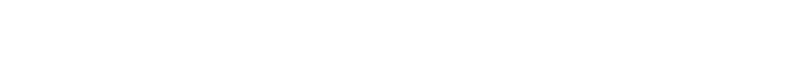
مطقة الجل الخضر بدولة ليبيا.
الحلبي عند مستوى الارفاع I كلن الأعلى في التأثير عل ه

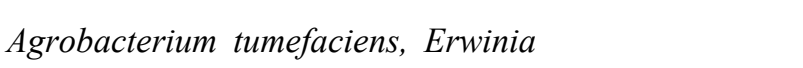
carotovora, Corynebacterium fascians and Pseudomonas solanacearum الطيارة المستخلصة من أوراق للسرو الإيطالي فكلن أعلا ه.

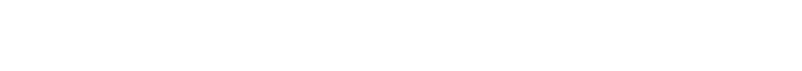
مستوى II

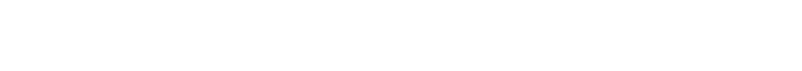

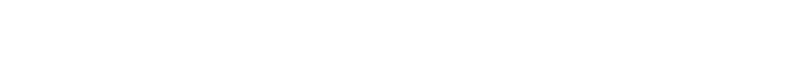

